старанність виконання, дизайн та естетичний вигляд слайдів, наявність розкриття п’яти понять 3 посиланням на наукову літературу.

У висновку зазначимо, що в педагогіці вищої школи Австралії оцінювання використовується як потужний інструмент навчання студентів та забезпечення якості навчальних програм і рівня підготовки фахівців. Упродовж курсу навчання студентів формативне оцінювання здійснюється у формі миттєвого фідбеку, окрім професійноособистісних умінь, знання та навички здобуваються в результаті роботи над завданнями для підсумкового оцінювання кожного семестру. Перспективним напрямом подальших розвідок $€$ розроблення методичних рекомендацій з питань імплементації нових видів завдань для оцінювання в умовах української вищої школи.

\title{
Література
}

1. Свропейський досвід для створення ефективної системи контролю та оцінки якості вищої освіти в Україні. Аналітична записка [Електронний ресурс] / М. Карпенко // Інститут стратегічних досліджень при Президентові Україні. - Режим доступу: http://www.niss.gov.ua/articles/745/ 2. Black P. \& Jones J. 'Formative assessment and the learning and teaching of MFL: sharing the languages learning road map with the learners', in Language Learning Journal, 34, Issue 1, 4-9. Reprinted by permission of the publisher, Taylor \& Francis Ltd, 2006. 3. Brookhart S. M. Assessment theory for college classrooms. New directions for teaching and learning, 2009. - 100 p. 4. Learning and Teaching in Higher Education. The reflective professional. Second Edition. Greg Light, Roy Cox, Susanna Calkins. TJ International Ltd, Padstow, Cornwall, 2009. 5. Teaching and Learning Languages. A Guide. Angela Scarino, Anthony J Liddicoat. Funded by the Australian Government Department of Education, Employment and Workplace relations. -100 p. 6. The University of Sydney. Faculty of education and Social Work. EDUP4007. Primary Languages A. Unit of Study Outline, Session 1, 2012. 7. The University of Sydney. Faculty of education and Social Work. EDUP4008. Primary Languages B. Unit of Study Outline, Session 2, 2012.

УДК 37(09):008

Марина Сіренко

\section{КОНЦЕПТ МАТЕРИНСТВА ЯК СКЛАДНИК ПЕДАГОГІЧНОЇ КУЛЬТУРИ СУСПІЛЬСТВА}

Сіренко М. В. Концепт материнства як складник педагогічної культури суспільства.

Стаття присвячена аналізу стану вивчення концепту материнства як складника педагогічної культури суспільства, окресленню його педагогічних функцій. Концепт материнства розуміється як когнітивна засада жіночого та чоловічого світовідношення, практичної поведінки, культурної діяльності та як складник сучасної педагогічної культури суспільства.

Ключові слова: материнство, концепт материнства, педагогічна культура, педагогічні функції, суспільство.

Сиренко М. В. Концепт материнства как составляющая педагогической культуры общества.

Статья посвящена анализу состояния изучения концепта материнства как составляющей педагогической культуры общества, выделению его педагогических функций. Концепт материнства рассматривается как когнитивная основа женского и мужского соотношения, прктического поведения, культурной деятельности и как составляющая современной педагогической культуры общества.

Ключевые слова: материнство, концепт материнства, педагогическая культура, педагогические функции, общество.

Sirenko M. V. The concept of Motherhood as a component of society pedagogical culture.

The article is devoted to the analysis of the concept Motherhood as a component of society pedagogical culture, outlines its educational functions. The concept of motherhood is understood as a cognitive principle of woman's and man's outlook, practical behavior, cultural activities and as a component of modern society educational culture.

Key words: Motherhood, the concept of Motherhood, pedagogical culture, pedagogical functions, society. 
Останні десятиріччя XX століття та початок XXI століття в більшості розвинутих країн індустріального типу, зокрема i в Україні, позначені зростанням кризових явищ в галузі сімейної життєдіяльності сучасної людини. Зменшується загальна кількість сімей, що утворюються на кожну тисячу населення. Шлюб все більше втрачає статус обов'язкової й очікуваної події в житті кожної молодої людини. Народження власної дитини далеко не в кожного молодого чоловіка і молодої жінки шлюбного віку є складником власного життєвого проекту. Ці обставини вимагають переосмислення загальнокультурного концепту материнства як складника педагогічної культури суспільства, та з'ясування його педагогічних функцій, об'єднання зусиль педагогічної науки, сім'ї, школи та інших соціальних інститутів в справі навчання і виховання майбутніх матерів.

Концептосфера, обрана нами для дослідження, $\epsilon$ недостатньо вивченою. Наявні дослідження, присвячені аналізу концептів, близьких до концепту материнства та пов'язаних 3 ним. Це дисертації Н. Даниленко «Формування психологічної готовності жінки до материнства» (2007), Н. Максимовської «Формування культури материнства жіночої молоді у соціально-педагогічному середовищі вищого навчального закладу» (2008), М. Матвєєвої «Концепт «Родина» і його репрезентація в російській мові» (2007), Н. Паскової «Концепт «Жінка» в текстах середньоанглійського періоду» (2003), О. Петренко «Виховання любові до матері у педагогічній спадщині В. Сухомлинського» (1997), Н. Рудової «Система виховання ціннісного відношення до материнства» (2009), О. Смирнової «Образи матері і батька у фразеології різноструктурних мов» (2009), О. Чібишевої «Концепт «Жінка» в російській та англійській фразеології» (2005) тощо. Як бачимо, лише деякі із названих праць безпосередньо торкаються педагогічних складників концептів «мати», «жінка» й подібних.

Mema cmammi - схарактеризувати концепт материнства як складник педагогічної культури суспільства, а також окреслити його педагогічні (виховні, освітні, формувальні) функції.

Сучасний методологічний та культурологічний термін «концепт» (від лат. conceptus) означає «поняття». Концепт 3 погляду характеристики процесу людської діяльності - це сукупність усіх уявлень і програм практичної діяльності, які пов'язуються зі змістом того поняття, яке використовується тією чи тією особою. За своїм змістом і значенням термін «концепт» віддзеркалює різноманітні форми людської культурної діяльності, зокрема педагогічної, і є наближеним до термінів «уявлення», «поняття», «модель», «програма», «установка», «зразок», «норма», «правило», «принцип». Концепт поєднує внутрішні програми педагогічної діяльності людини. «Концепт - це ніби конденсований сегмент культури у свідомості людини, те, у вигляді чого культура входить до ментального світу людини. 3 іншого боку, концепт - це те, засобами чого пересічна людина - звичайна людина, не «творець культурних цінностей» - сама входить у культуру, а у деяких випадках й впливає на неї» $[6, \mathrm{c}$. 42]. «Входження культури до ментального світу людини» - це за своїм змістом процес педагогічний, тому що культура засвоюється особою в процесі виховання, освіти, навчання. Коли батьки або вчителі пояснюють дитині, що таке «добре», а що таке «погано», вони озброюють ії знанням про людські оцінки вчинків, поведінки, про правила і норми життя. Це знання закріплюється в пам'яті. Розширення знання про світ, суспільство, людські стосунки це перший значущий наслідок оволодіння новим для дитини концептом. Другий значущий наслідок - оволодіння новими словами, вмінням їх використовувати у відповідній ситуації у спілкуванні. Якщо дитині розповіли, що таке «добре» та що таке «погано», з нею вже можна про це говорити на доступному для неї мовленнєвому рівні, вона здатна відповідати на питання дорослих і однолітків, давати власні визначення відповідно до свого віку.

Але це лише поверхневі, хоча і значущі наслідки оволодіння якимось концептом у виховному процесі, i торкаються вони лише галузі знання і комунікації.

Більш глибокими наслідками є ті, які торкаються процесу формування особистості, внутрішнього «образу Я» і дійсних мотивацій учинків, стосунків, поведінки.

Як «вивчений» та «запам'ятований» концепт («добре», «погано») увійде до структури індивідуальності та особистості. Але чи знайде він там своє місце, а також чи вплине він колись на вчинок дитини (майбутнього підлітка, дорослого) - цього заздалегідь ніхто не може сказати. Сфера «Я», властивості особистості та її реальні вчинки висвітляться лише колись у життєвому досвіді. 
Тобто лише набагато пізніше можна буде побачити, як кожна окрема дитина насправді «увійшла в культуру» та у який спосіб вона впливає на неї.

Материнство є соціально-психологічним феноменом, утвореним сукупністю почуттєвих і раціональних компонентів психіки людини, емоційних переживань, знань, уявлень та переконань стосовно себе в материнській ролі, які реалізуються у всіх виявах поведінкового складника материнства [3, с. 13].

Якщо «концепт» - це система знань та сукупність програм практичної людської діяльності, то «концепт материнства» можна інтерпретувати як сукупність уявлень людини (як людства взагалі, так і кожної окремої дівчини, жінки) про материнство, інтегрованих $з$ програмами оволодіння певними знаннями, вміннями, навичками відповідного виду діяльності. Материнство можна вважати різновидом людської діяльності, пов'язаного з найбільшою відповідальністю у світі. Це велике мистецтво, якому необхідно вчитися. Причому починати осягати мистецтво бути матір'ю необхідно ще задовго до моменту вагітності [4, с. 69]. Оволодіння маленькою дівчинкою уявленнями про цінності материнства, материнські ролі, функції, завдання починається дуже рано - в ранньому дитячому віці і триває все подальше життя. У дитинстві у кожної людини закладається ставлення до довкілля і до самої себе. Якщо в ранньому віці дівчинка бачить перед собою матір як джерело впевненості, турботи, розуміння, любові, безпеки то, по-перше, індивідуальний розвиток відбувається правильно і гармонійно, по-друге, вона вбирає в себе позитивні материнські установки і програми поведінки [2].

Після оволодіння первинними формами материнсько-дитячої взаємодії в ранньому віці діти починають «приміряти» роль матері на себе у грі «доньки-матері». Головним у таких іграх $\epsilon$ те, що дівчинка бере на себе роль матері стосовно ляльки. Саме у грі відбиваються ті материнські інтенції, що відчуває дівчинка щодо себе і копіює поведінку дорослих, переносячи свої дії на ляльок та інші іграшки. Приміряючи на себе роль матері, дівчинка вчиться догляду за дитиною: годувати, одягати, гуляти 3 нею, укладати. I все це відбувається у неперервному «спілкуванні» 3 лялькою. Відтак відбувається оволодіння розмаїттям вербальних і невербальних форм спілкування майбутньої матері 3 ляльковою «дитиною». Водночас відбувається оволодінням розмаїттям культурних материнських емоцій та навичок: любити, милуватися, турбуватися, пишатися, оберігати. Це дуже важливий етап оволодіння психоемоційними складниками програми материнства i, чим успішніше він буде пройдений, тим імовірніше, що в майбутньому материнство принесе жінці дійсну радість.

Між 6 і 10 роками сюжетно-рольова гра вже не так цікава, і дівчинці хочеться робити щось «по-справжньому», тому відпрацьований на ляльках досвід інколи закріплюється і у спілкуванні 3 реальними малюками. Це можуть бути племінники, сестри, брати та ін. Тут формується позитивний досвід, у якому дівчинка, спостерігаючи за малюком, зрозуміє: дитина - це добре.

У підлітковому віці інтереси мають інтимно-особистісний характер, тому, якщо в родині з'являється ще одна дитина, не варто насильно змушувати няньчитися з малюком. Дівчині вже не до малюка, i, якщо іiі змушувати няньчитися проти волі, то це може призвести до формування ставлення до дитини як до тягаря і завади. У цей період мати повинна допомогти дівчині пережити всі моменти дорослішання, бути подружкою або порадницею, розповісти про принади материнства і таїнства інтимних стосунків.

Особливо значущий етап у формуванні концепту материнства - період статевого дозрівання. Завжди і у всі часи радість статевого кохання мала пряме відношення до радості материнства. Зміни настали в Новий час, вони пов'язані з частковою емансипацією жінок. Ці дві галузі життя виявилися розділеними і все далі відмежовуються одна від одної. Досягнення сучасної медицини взагалі може забезпечити акт зачаття без контакту зі статевим партнером, а контакт з партнером - без перспектив народження дитини. Більше того, пропаганду саме таких «безпечних» стосунків ми спостерігаємо у сучасних засобах масової інформації. Зрозуміло, що найгостріше ця тема сприймається в ранній юності. Суспільне визнання дозволеності статевих відносин у цьому віці і поза шлюбом поставило перед сім'єю низку серйозних проблем, а перед розвинутими сучасними соціумами - загрозу демографічного вимирання.

На противагу цьому ми можемо спостерігати впровадження з 1982 року в загальноосвітніх закладах дворічного курсу «Етика та психологія сімейного життя» (10-11 класи), головними завданнями якого є: підвищення відповідального ставлення молоді до проблем шлюбу та сімейного життя; формування в юнаків та дівчат високого рівня етико-психологічної культури; 
підвищення соціальної престижності ролі батьківства та материнства; формування психологічної готовності юнаків та дівчат до шлюбу; висвітлення питання ведення домашнього господарства, організації бюджету сім'ї тощо.

Бурхливий розвиток індивідуальних уявлень про власне материнське призначення відбувається в період вагітності. Плід, що розвивається в утробі матері протягом багатьох місяців, $\epsilon$ частиною тіла матері і не може уявлятися у відриві від нього. Саме з відчуття внутрішньої єдності матері і дитини у жінки виникають перші справжні материнські почуття, 3 яких найголовніше - турбота про дитину. Тут турботу про дитину можна розглядати на кількох рівнях:

1. Соціальний рівень: планується майбутнє життя сім'ї, яка має дитину, у чому й полягає ії якісна відмінність від сім’ї, у якій дитини немає. Це новий «образ життя», «стиль життя», «спосіб життя» - в економічному, соціально-комунікативному, соціально-культурному вимірах. І на цьому етапі сім'я та ії члени перетворюються на суб'єктів педагогічної діяльності.

2. Фізичний рівень: формується свідоме ставлення до харчування (майбутні матері вибирають здорову, корисну їжу і збалансоване меню); заняття спортом і нарешті - ведення здорового способу життя.

3. Емоційний рівень: вагітні жінки намагаються уникати стресових ситуацій або свідомо придушувати небажані емоції і навпаки культивують у собі «стан щастя» і внутрішньої свободи, передаючи його дитині.

4. Естетичний рівень: музика, поезія, співи, мистецтво, природа допомагають досягти гармонійного внутрішнього стану і виховують у дитині почуття прекрасного. Тут важливу роль починає відігравати і батько. Ставлення до дружини, до ії вагітності і до очікуваної дитини найважливіші чинники, що формують у цієї дитини відчуття щастя і сили, яке передається йому через упевнену в собі і спокійну матір.

5. Ментальний рівень: жінки мають добре розвинену уяву і здатні успішно використовувати цю якість при формуванні своєї майбутньої дитини. Наприклад, жінка може спробувати уявити собі ті якості, які вона хотіла б бачити у своєї дитини, і досягти реалізації своєї мрії [5].

Але народити дитину ще недостатньо, щоби стати матір'ю. Жінку, яка залишила в пологовому будинку власну дитину, навряд чи можна назвати матір'ю.

Турбота матері про дитину $є$ різнобічною. Все, що вона робить для дитини, формує $\mathrm{i}$ поглиблюе іï власні нові материнські якості. Втамовуючи почуття голоду дитини, стежачи за ії чистотою, здоров'ям, небезпечністю, розвитком, мати задовольняє не тільки потреби дитини, але й свої. Єдність, яка встановилась між матір'ю і дитиною 3 перших днів іiї існування, з часом змінюється, набуває нових форм, стає просто прив'язаністю, але назавжди залишиться єдністю матері та дитини. Порушення цієї емоційної єдності згубно позначається не тільки на дитині, але й на самій матері. Від перших почуттів, якими мати обмінюється 3 дитиною і які стають важливими життєвими уроками для обох, мати за законами, даними їй природою, переходить до більш складного спілкування з дитиною - навчання, виховання, формування, які не в змозі забезпечити повною мірою ні батько, ні будь-хто інший. Це навчання починається 3 мови. Залучаючи дитину до мови і вслухаючись у звуки, вигукнуті дитиною, лише мати в змозі зрозуміти, що саме хоче висловити дитина. За допомогою мови матір вводить дитину у світ людей, $з$ якими ій доведеться жити, допомагає побачити цей світ не тільки «зовні», але і «зсередини», не тільки відкриває перед нею явища, але й допомагає їй осягнути їх суть. Мати не просто спрямовує дитину на якісь вчинки, але й своїми коментарями вчить оцінювати їх, що в світі дорослих, куди вступає дитина, відіграє провідну роль. Гармонійно розвинена особистість ніколи не задовольняється досягнутим: оцінюючи себе й інших, вона шукає в собі нові резерви для досягнення більш значущих результатів. Не слід змішувати почуття задоволення від виконаної роботи з почуттям самозадоволення. Ці перші уроки самооцінки також надає своїй дитині мати, спонукаючи іiі до нових позитивних учинків і оберігаючи від неправильних. Завдяки мові дитина відчуває себе впевнено у світі дорослих, мова допомагає дитині усвідомити себе індивідуальністю зі своїми особливими бажаннями і потребами.

Ніхто інший, як мати стоїть біля витоків такої важливої в житті кожної людини якості, як уміння правильно орієнтуватися в соціальному середовищі. Хто ми такі, як взаємодіємо 3 іншими людьми, що можемо дозволити собі, а що не можемо - це і багато іншого, що допомагає людині жити повноцінним життям, значною мірою залежить від того, наскільки правильно була соціально зорієнтована людина в дитинстві. Разом з першими соціальними та 
культурними поняттями дитина повинна отримати перші уявлення про справедливість і несправедливість, добро і зло, моральність та аморальність. Вперше навчає цьому дитину саме мати. Неоціненною є роль справжньої матері в розумному статевому вихованні дітей [1, с. 47].

Отже, концепт материнства є значущим складником педагогічної культури суспільства. Його засвоєння кожною людиною пов'язане з багатьма процесами педагогічного змісту: виховними, освітніми, формуючими. Материнство $є$ великим мистецтвом, і його необхідно навчатися, готуватися до цього найважливішого кроку свідомо і з самого дитинства. I на кожному віковому етапі майбутня мати має осягати елементи «знання материнства», а ставши матір'ю - не тільки грамотно доглядати за дитиною, але і правильно виховувати ії. Адже мати - початок початку кожної сім'ї, і дитина прислухається насамперед до матері, у ній шукає свою головну підтримку, у неї отримує перші уроки життя. Від матері більшою мірою залежить, чи стане життя дитини щасливим або буде понівеченим, чи виросте 3 неї повноцінна людина або в іiі особі суспільству буде тягар. Тільки жінка, яка подарувала дитині життя та нормальне дитинство, що зуміла виховати повноцінну особистість, може бути впевненою у ії майбутньому. Концепт материнства як когнітивна засада жіночого та чоловічого світовідношення, практичної поведінки, культурної діяльності та як складник сучасної педагогічної культури суспільства, зважаючи на сучасні соціокультурні та демографічні обставини, повинен інтенсивно досліджуватися й активізуватися в сучасних технологіях виховання і навчання дітей, підлітків, молоді дошлюбного і шлюбного віку.

\section{Література}

1. Алєксєєнко Т. Ф. Молода сім'я: умови виховання дитини / Т. Ф. Алєксєєнко. - К., $2004-96$ с. 2. Никольская И. Н. Дочки-матери или отношение к будущему материнству [Електронний ресурс] / И. Н. Никольская. - Режим доступу : http://www.child-hood.ru/index.php/psychology-age-pre/708mothers-and-daughters-or-relation-to-the-future-of-motherhood.html 3. Овчарова Р. В. Психологическое сопровождение родительства / Р. В. Овчарова. - М. : ЗАО «Институт психотерапии», 2003. - 295 с. 4. Рамих В. А. Материнство и культура (Философско-культурологический анализ) / В. А. Рамих. Ростов-на-Дону : Издательский центр ДГТУ, 1997. - 145 с. 5. Сознательное, положительное отношение к плоду во время беременности [Електронний ресурс] / Режим доступу : http://www.psichology.vuzlib.org/ book_0678_page_9.html 6. Степанов Ю. С. Концепт / Ю. С. Степанов // Степанов Ю. С. Константы : Словарь русской культуры. - [3-е изд. ]. - М.: Академический проект, 2004. - С. 42-67.

УДК 371.68:378.14(4)

Микола Стрюк

\section{ВИТОКИ МОБІЛЬНОГО НАВЧАННЯ У КРАЇНАХ ЄВРОПЕЙСЬКОГО СОЮЗУ}

Стрюк М. І. Витоки мобільного навчання у країнах Європейського Союзу.

У статті на основі нових історико-педагогічних джерел досліджено витоки мобільного навчання у країнах Європейського Союзу та співвідношення різних видів мобільності (соціальної, географічної, професійної, академічної та ін.) у соціально-педагогічних системах.

Ключові слова: мобільність, мобільне навчання, Свропейський Союз.

Стрюк Н. И. Истоки мобильного обучения в странах Европейского Союза.

В статье на основе новых историко-педагогических источников исследованы истоки мобильного обучения в странах Европейского Союза и соотношение различных видов мобильности (социальной, географической, профессиональной, академической и др.) в социально-педагогических системах.

Ключевые слова: мобильность, мобильное обучение, Европейский Союз.

Stryuk M. I. Origins of Mobile Learning in the European Union.

On the basis of new historical and pedagogical sources researched the origins of mobile learning in the European Union and the correspondence of different types of mobility (social, geographical, professional, academic, etc.) in social and educational systems.

Keywords: mobility, mobile learning, the European Union.

«Національна стратегія розвитку освіти в Україні на період до 2021 року» [19] визначає напрями перебудови вітчизняної системи освіти у зв'язку з необхідністю ії інтеграції в 